\title{
The Choice Problems Of Presidential System In Indonesia Post- Reformation
}

\author{
Siti Rodhiyah Dwi Istinah*), Aryani Witasari ${ }^{* *}$, Fajar Fathan Fuadi**) and \\ Muhammad Ali Maskun ${ }^{* * * *}$ ) \\ *) Faculty of Law, Unversitas Islam Sultan Agung Semarang, E-mail \\ rodhiyah@unissula.ac.id \\ $\left.{ }^{* *}\right)$ Faculty of Law, Unversitas Islam Sultan Agung Semarang, E-mail: \\ aryani@unissula.ac.id \\ ${ }^{* * *)}$ Universitas Wahid Hasyim Semarang, E-mail: muh fattan@unwahas.ac.id \\ ${ }^{* * * *}$ Employee of Bank Mandiri, E-mail: alimaskun168@gmail.com
}

\begin{abstract}
The purpose of this paper is to find out and analyze the problems of the choice of the presidential system in the post-reformation of Indonesian state administration. The research method used is normative juridical, using a statutory approach. The data used is secondary data, with primary legal material from the 1945 Constitution and other laws and regulations. The results show that the choice of a presidential government system becomes a problem when juxtaposed with the multi-party system (combined phrase of political parties) in the 1945 Constitution. The MPR in the trial between 1999 and 2002 did not choose a quasi-presidential system in the original 1945 Constitution as well as a parliamentary system and explicitly transplant the American-style presidential system of government, without paying attention to ideological reasons and the identity and traditions of the state that have been explored by the nation's founders such as Soepomo, Soekarno and Muhammad Hatta.

Keywords: Administration, Post-Reformation; Presidential; Problematic; System.
\end{abstract}

\section{Introduction}

One of the results of the amendment to the 1945 Constitution is changing the Indonesian state administration system from power in the MPR to a people's sovereignty system, which places the position of state institutions in an equal position. In the development of the nation state, the concept of sovereignty has the meaning that people's sovereignty can be interpreted when the people are given the authority to directly choose the environment of the head office and the environment of the representative office. The election for the office of headship is marked by, among other things, the holding of the election of the President and Vice President (Article 6A of the 1945 Constitution) in the Indonesian constitutional system. This general election can be a marker of the characteristics of a presidential system of government where the previous presidential election was carried out by the MPR institution. As a manifestation of democracy, one of the measures in assessing the success of holding a general election is political participation which is realized by granting voting rights by people who already have the right to vote. ${ }^{1}$

\footnotetext{
1 Joko Susilo \& Siti Rodhiyah Dwi Istinah, "Peran Komisi Pemilihan Umum Daerah Kabupaten Semarang Dalam Meningkatkan Partisipasi Politik Masyarakat Pada Pemilu Serentak 2019" in the Proceedings of the
} 
The presidential government system has the advantage that the government run by the executive runs relatively stable and in accordance with the time limit that has been regulated and stipulated in the constitution. While the weakness of the presidential government system is that every government policy taken is a bargaining position between the legislature and the executive, which means that there is a prioritization of representative - elitist and not participatory - populist attitudes. ${ }^{2}$

Constitutional theory has long held that the separation of powers is unique to presidential systems and incompatible with parliamentary ones. This conventional wisdom has hardened over the years with the proliferation of scholarship debating the merits of presidential or parliamentary systems for emerging democracies or reconstructed states. ${ }^{3}$

The choice of a presidential government system with a direct election model is similar to the presidential election in the United States, although it differs in socio-economic and political culture and democratic maturity. However, if explored further when the ideas of the founding fathers at the meeting of the Basic Law Committee formed by BPUPKI, on July 11, 1945 an agreement was reached that the Republic of Indonesia was not suitable to use an individualistic parliamentary system. The presidential system is seen as unsuitable for Indonesia, because according to them, each has its own weaknesses. The newly independent Indonesia will use the "own system" according to Soekiman and Soepomo's proposal. Experts use different terms to name the typical Indonesian system. Ismail Suny calls it Quasi-presidential, ${ }^{4}$ The thinking of the founding fathers was based on the choice of rejecting pure parliamentary democracy because it reflects capitalistic values and also rejects a centralized totalitarian socio-economic system, because of that understanding in the 1945 Constitution is people's sovereignty which is collective, not people's sovereignty with an individualistic character.

Several articles in the 1945 Constitution regulate the President's authority, thus the 1945 Constitution is the main source that regulates the President's authority. ${ }^{5}$ The President runs the government according to the Constitution, but Article 1 paragraph (2) of the 1945 Constitution formulates that the highest source of power or sovereignty is in the hands of the people, which is how to implement it according to the Constitution. their duties and authorities are according to the 1945 Constitution, and there is also a part where people's sovereignty is carried out directly by the people in determining or choosing the environment of head office such as choosing the President and regional heads and village heads, as well as in choosing representative positions such as choosing members of the DPR, DPD and DPRD. Province, Regency and City in every general election.

The government system that applies in every country is essentially a relation between

\footnotetext{
Unissula Student Scientific Conference (KIMU) 2 Universitas Islam Sultan Agung Semarang, 18 October 18 2019, page 532, http ://jurnal.unissula.ac.id/index.php/kimuh/article/view/8861/4038

2 Ribkha Annisa Octovina, Sistem Presidensial di Indonesia, CosmoGov: Jurnal Ilmu Pemerintahan, ISSN 2442-5958 E-ISSN 2540-8674, Vol.4, No.2, October 2018

${ }^{3}$ Richard Albert; Presidential values in parliamentary democracies, International Journal of Constitutional Law, Volume 8, Issue 2, 1 April 2010, Pages 207, https://doi.org/10.1093/icon/moq008

${ }^{4}$ Sofian Effendi, 2018, Sistem Pemerintahan Adalah Jati Diri Bangsa, Makalah, UGM, Yogyakarta.

5 Philipus M Hadjon, 1991, Pelimpahan Tugas \& Wewenang Kepada Presiden, Dalam Rangka Mensukseskan \& Mengamankan Pembangunan Nasional, Makalah, Universitas Airlangga, Surabaya
} 
the axis of executive and legislative power. The presidential system focuses mainly on the axis of government power (executive) held by the President, while the parliamentary system of government axis of power is on the legislature (parliament). The amendment to the 1945 Constitution brought with it the choice of the government system from a quasi-presidential system to a (pure) presidential system, based on the results of the MPR agreement when it was about to make changes to the 1945 Constitution in 1999.Problems arise when several articles containing the results of the amendment to the 1945 Constitution do not show the characteristics of a presidential system (pure) which was agreed to be the choice of the MPR, but other characteristics of the government system will characterize the government system in Indonesia. The results of Retno Saraswati's research include that constitutionally Indonesia adheres to a presidential government system, a proportional electoral system and a multi-party system. In his research, he said that currently, democratic governments have not found an ideal and stable building, this is inseparable from the incompatibility of the three building systems. The formulation of the presidential system as regulated in the 1945 Constitution, turned out to be difficult to implement. ${ }^{6}$

\section{Research Methods}

This research uses a normative juridical approach or a normative-legal research approach. This type of research is an analytical descriptive research, namely research that wants to provide an overview of the choice of government system in the 1945 Constitution after the MPR agreement in the trial to make changes to the 1945 Constitution. The source of data used in this study is secondary data. Secondary data in the form of library data in the form of documents, archives, legislation, and various literature. The collection of legal materials is carried out by conducting an inventory of research materials using legal library materials related to this research, by tracing, grouping library materials conventionally by seeing, reading, listening, as well as using information technology (internet media). The legal materials are processed with the stages of structuring, describing, and systematizing legal materials. Secondary data in the form of primary legal materials, secondary and tertiary legal materials collected will be inventoried and identified which will then be analyzed deductively with qualitative discussion, using normative methods by analyzing the choice of presidential government system and its problems in the Indonesian state administration.

\section{Results and Discussion}

Quoting the opinion of A. Hamid S. Attamimi the government system is defined as parts of the government (all government organs) where each has its own duties and functions. But as a whole, the parts are a unity that must work together rationally. ${ }^{7}$ Maduabuchi

\footnotetext{
${ }^{6}$ Retno Saraswati, Desain Sistem Pemerintahan Presidensial yang Efektif, Faculty of Law, Universitas Diponegoro Semarang, MMH, Volume 41 No. January 1, 2012

${ }^{7}$ Hamid S. Attamimi, 1990, Peranan Keputusan Presiden Republik Indonesia Dalam Penyelenggaraan Pemerintahan Negara, Suatu Analisis Mengenai Keputusan Presiden Yang Berfungsi Pengaturan Dalam Kurun Waktu pelita I-Pelita IV, Disertasi, Fak. Pascasarjana UI, Jakarta. p. 110 see Sri Soemantri, 176, Sistem-Sistem Pemerintahan Negara-Negara Asean, Tarsito, Bandungp. 19-20
} 
(2001) and Andre (1994) agree that while the executive as a form of government is responsible for policy formulation, evaluation and execution to realize set targets, the legislature enacts laws and make the same functional as instrument of cohesion in the society. The belief here is that all the levels of government, be they executive, legislature and judiciary, each of them may not necessarily subsist without the other meaning that each organ of government is mutually reinforcing and contingent upon the success or failure of the other. ${ }^{8}$

CF Strong divides the government system into the categories of Parliamentary executive and non-parliamentary executive or the fix executive. The first parliamentary system was implemented in the British Empire to replace the absolute monarchy system that had lasted so long that England was considered the mother of the parliamentary system. This system has a long history through constitutional customs which are commonly called conventions of the constitution.

In the UK, and other common law jurisdictions, the executive and legislature are closely entwined. The Prime Minister and a majority of his or her ministers are Members of Parliament and sit in the House of Commons. The executive is therefore present at the heart of Parliament. ${ }^{9}$ Parliamentarism is understood as a system of government in which the executive is chosen by, and responsible to, an elective body (the legislature), thus creating a single locus of sovereignty at the national level. ${ }^{10}$

The general characteristics of a parliamentary government system from Alan R. Ball as quoted by Sri Soemantri provide 3 kinds of characteristics of a parliamentary government system, namely:

- There is nominal head of state who use function are chiefly formal and ceremonial and whose political influence is small. This head of state may be a monarch, as in the united kingdom, Japan or Australia, or a president, as in West Germany, India or Italy.

- The political executive, the primary minister, chancellor etc, together with the cabinet, is part of the legislature, and can be removed by the legislature if the legislature with draws its support.

- The legislature is elected for varying period by the electorate, the election date being chosen by the formal head of state on the advice of the primary minister or chancellor ${ }^{11}$

The birth of a presidential system of government cannot be separated from the birth of the United States of America which is trying to break away from the British colony. One of the characteristics of the presidential government system is the implementation of direct presidential elections, such as in several countries, such as Brazil, Uruguay, Finland, Austria, Portugal, Poland and the United States, as well as in Indonesia, despite

\footnotetext{
${ }^{8}$ Uchem Raphael Onyebuchi, "Executive, Legislative Relations In Parliamentary And Presidential Government", in Global Journal of Arts Humanities and Social Sciences Vol. 1 No. 3, p. 14-19, September 2013 [Published by European Centre for Research Training and Development UK (www.ea-journals.org), p. 15.

${ }^{9}$ Richard Benwell and Oonagh Gay, The Separation of Powers,Standard Note: SN/PC/06053, House of Commons Library, p. 3.http://researchbriefings.files.parliament.uk/documents/SN06053/SN06053. pdf.

${ }^{10} J o s e ́$ Antonio Cheibub, Zachary Elkins and Tom Ginsburg, "Beyond Presidentialism and Parliamentarism", British Journal of Political Science, Available on CJO 2013 doi:10.1017/S000712341300032X, p 4.

${ }^{11}$ Sri Soemantri, 1976, Sistem Pemerintahan Negara-Negara ASEAN, Tarsito, Bandung, p. 37
} 
their different political and socio-economic cultures as well as their democratic maturity. Saldi Isra, citing the opinion of Alan R. Ball and Peters, suggests the following characteristics of a presidential system:

- The president is both nominal and political head of state.

- The president is not elected by the legislature, but is directly elected by the total electorate. (There is an electoral college in the United States, but it is of political significance only in that each state votes as unit and hence the system tends to disadvantage small parties).

- The president is not part of the legislature, and he cannot be from office by the legislature except through the legal process of impeachment.

- The president cannot dissolve the legislature and call a general election. Usually the president and the legislature are elected for mixed terms. ${ }^{12}$

Regarding the presidential system, two things need to be considered in the country based on the Republic, namely, President and Presidential system....However, not all countries based on the Republican system have a Presidential System in which the President acting as the head of state as well as the head of government. In the Republic of Singapore, for example, the head of the state is on the hand of the President, while the system of government is parliamentary. Thus, the President is not synonymous with a Presidential system. Similarly, the parliamentary system is not identical to the form of government Monarchy. ${ }^{13}$

The 1945 Constitution before the amendment placed the MPR as the highest state institution which was formulated in Article 2 paragraph (1) of the 1945 Constitution that the MPR had a membership consisting of members of the DPR plus delegates from regions and groups. The MPR is a body that carries out the sovereignty of the people and as a place for deliberation for representatives and groups who represent the community in the MPR Institution. In addition, there are provisions in Article 4 and Article 17 of the 1945 Constitution which indicate that the 1945 Constitution adheres to a presidential system of government, where the President becomes the chief executive and appoints and dismisses the ministers who are responsible to him. The provisions of Article 6 paragraph (2) of the 1945 Constitution prior to the amendment stated that the President and Vice President were elected by the MPR with the majority of votes. If the DPR is of the opinion that the President has deviated from the outlines of the state policy, then the DPR with TAP MPR No. III/MPR/1978 concerning the Position and Work Procedures of the Highest State Institutions with/or between High State Institutions, the President may be dismissed during his term of office. The Indonesian government system in the 1945 Constitution before the amendment was called a mixed system (quasi), because it contained the characteristics of a presidential government system, and the characteristics of a parliamentary system of government.

One of the demands of reform is to amend the 1945 Constitution. The MPR agreement before making changes to the 1945 Constitution included the use of a presidential system, by taking steps to amend several articles in the 1945 Constitution, namely:

\footnotetext{
${ }^{12}$ Allan R. Ball \& B. Guy Peters, 2000, Modernn Politics and Government, edisi ke-6, Macmillan Press Ltd, p. 62 in Saldi Isra, 2010, Pergeseran Fungsi Legislasi, Rajawali Pers, Jakarta, p. 38-39

${ }^{13}$ Muhammad Asrun, The Practice of Presidential System in Indonesia, Scientific Research Journal (SCIRJ), Volume III, Issue IV, April 201515 ISSN 2201-2796, www.scirj.org, p. 16
} 
- The President and Vice President are elected by the people directly through general elections, Article 6A paragraph (2); and proposed by a political party or coalition of political parties participating in the general election prior to the implementation of the general election;

- The President and Vice President hold office for five years, and thereafter can be reelected for only one term of office, Article 7;

- The President and Vice President may be dismissed during their term of office by the MPR at the suggestion of the DPR, Article 7A, Article 7B

System government Indonesia is currently more visible as a system presidential. However, there are still parliamentary characteristics, the main presidential characteristics are still more prominent. The parliamentary element is to strengthen the position of the DPR by entering the scope of the president's power. In Article 13 paragraphs (2) and (3): In terms of appointing ambassadors, the President takes into account the considerations of the House of Representatives. Likewise, when the President accepts the placement of ambassadors from other countries by taking into account the considerations of the House of Representatives, elects members of the Supreme Audit Agency (BPK Article 23F paragraph (1)), gives approval in the appointment of Supreme Court Justices at the Supreme Court (MA, Article 24 A paragraph (3)). ) and approval and dismissal of Members of the Judicial Commission (KY, Article 24B paragraph (3)) as well as the submission of $1 / 3$ of the 9 (Nine) Constitutional Justices at the Constitutional Court (MK, Article 24C paragraph (3))

The normalization in the constitution shows a dilemma as well as a paradox of the strong position of the President in the presidential government system in the 1945 Constitution. Likewise, the expansion of the power of the DPR in the executive realm in filling state officials starting from giving approval, choosing, giving consideration and proposing state officials regulated in various laws and regulations, such as the Commander of the Indonesian National Armed Forces (TNI), the Chief of the Indonesian National Police (Kapolri), the Governor of Bank Indonesia (BI), KPU, Komnas HAM Members, KPK Members, Financial Services Authority and so on. Likewise, the DPR does not only elect members, but also elects the chairman of the KPK, KPU and OJK. ${ }^{14}$ This is also supported by the decision of the Constitutional Court which rejects the lawsuit over the involvement of the DPR in giving approval to the DPR in the appointment of the TNI Commander and the National Police Chief, arguing that there is a check and balances system in the Trias Politica concept, in the balance of power and mutual supervision between state institutions and building control of the people through the DPR as a representation of the people.

The existence of constitutional developments in relations between state institutions, especially the executive and legislative branches, indicates the choice of a mixed or quasi-presidential government system with the emergence of new powers of the DPR that enter the realm of the executive, although under the pretext of having a check and balances system. To find a balance between the executive and legislative axes, it is actually not possible to fully use a pure government system such as a presidential government system (United States) or a parliamentary system (UK). The choice of

\footnotetext{
${ }^{14}$ Mei Susanto, Rahayu Prasetya ningsih, \& Lailani Sungkar, Jurnal Penelitian Hukum De Jure Akreditasi LIPI: No: 740/AU/P2MI-LIPI/04/2016, Volume18 No.1, March 2018, p. 24. Accessed on February 16, 2021
} 
government system will of course adapt to the development of history, political system and political culture in each country, including in Indonesia ${ }^{15}$.

The development of the government system in the 1945 Constitution is the choice that is in line with the political system, socio-economic political culture? Or is this option actually still a problem in the Indonesian state administration? What about the position of the MPR and DPD in relations between state institutions in the presidential system in Indonesia? And what is the actual organizational structure of the parliament in the 1945 Constitution? Is it unicameral, bicameral or tricameral? Therefore, there is a need for further research on the position and relationship between these institutions. However, the problem is, with the widening of the DPR's authority in the political configuration in the parliament which is volatile and unstable and less democratic, the system for appointing high-ranking state officials in the presidential system is biased, even leading to corrupt and collusive practices. ${ }^{16}$ However, other circumstances can also occur when there is a balance between the executive and legislative (political parties in large numbers) which can lead to immobilism (paralysis) and stagnation (political deadlock). The President can be in a weak position, when the DPR uses its functions to carry out oversight, budgeting and legislation to hinder the President in carrying out his duties.

The choice of a government system in the 1945 Constitution that is in accordance with the political, social and cultural conditions of the Indonesian people is not the first thing to be done in the Indonesian state administration system, as the French model of mixed government system was chosen when the prime minister Mohammad Hatta was appointed by President Soekarno, who was then Vice President. President of the Republic of Indonesia. After some time, the semi-parliamentary system adopted in the 1949 KRIS and the parliamentary system model that existed in the 1950 Constitution was implemented at that time. The trial of the choice of the government system finally returned with a mixed system ${ }^{17}$ contained in the 1945 Constitution after the presidential decree from 1959 to 1999. The mixed government system was actually born from an effort to find a middle way to take the best from the parliamentary system and presidential government system to create harmonious relations between institutions contained in the constitution. Was the choice of the founding fathers over the mixed system in the original 1945 Constitution a choice that was in accordance with the early development of independence or did the political system and political culture until the end of the New Order government, showing a political configuration that was not yet democratic, until the amendment to the 1945 Constitution? Is the implementation of the government system in the 1945 Constitution in line with social, economic, and social developments? Politics and political culture at that time? Or in what choice is the government system (presidential) that must adapt to the growing socio-political conditions in Indonesia, or the socio-political conditions that must be adjusted or formatted to adapt to the choice of the presidential system of government in the 1945

\footnotetext{
${ }^{15}$ A Chuasanga, Ong Argo Victoria. (2019). Legal Principles Under Criminal Law in Indonesia and Thailand, Jurnal Daulat Hukum, Vol 2, No 1 (2019) http://jurnal.unissula.ac.id/index.php/RH/article/view/4218

${ }^{16} \mathrm{Ibid}$.

${ }^{17}$ By Padmo Wwahyono it was called the MPR system which was then followed by Soehardjo SS in each of his studies.
} 
Constitution as a result of the changes? Such conditions can also occur in other developing countries, especially those that choose a presidential system, such as in Latin American countries. or socio-political conditions that must be adjusted or formatted to suit the choice of a presidential system of government in the 1945 Constitution as a result of the amendment? Such conditions can also occur in other developing countries, especially those that choose a presidential system, such as in Latin American countries. or socio-political conditions that must be adjusted or formatted to suit the choice of a presidential system of government in the 1945 Constitution as a result of the amendment? Such conditions can also occur in other developing countries, especially those that choose a presidential system, such as in Latin American countries.

The 1945 Constitution requires refinement, because it was drafted in an urgent time, however the debates between BPUPKI members at that time showed a classy debate and it was realized that the 1945 Constitution was not perfect as Soekarno said in front of PPKI members. In the course of national political life, it showed an undemocratic political configuration until the reformation era in 1998, but with the same 1945 Constitution at the beginning of the reformation, a more democratic political configuration can be found marked by the birth of several legal products that are more responsive in character, such as 1) MPR Decrees No. VIII/MPR/1998 concerning the Revocation of TAP MPR No. IV/MPR/1983 concerning Referendum; 2) MPR Decree No. XIII/MPR/1998 concerning Limitation of the Term of Office of the President and Vice President of Indonesia; 3) MPR Decree No. XVII/MPR/1998 on Human Rights, This provision enhances the human rights provisions contained in the 1945 Constitution, such as Article 27, Article 28, Article 29 paragraph (2). The three decrees did not directly change the 1945 Constitution but touched the material content of the 1945 Constitution. The three MPR Decrees had encouraged the will to amend the 1945 Constitution starting from the community, government, and socio-political forces, including political parties at the time, which was followed later by the entry of the material in the amendment to the 1945 Constitution. This condition coincided with the emergence of the era of globalization with issues of democratization, the environment and human rights, especially in developing countries at the end of the 20th century.

Amendments to the 1945 Constitution are the result of a political agreement (resultant) in formulating the same will which is influenced by social, political, economic and defense and security conditions that developed in the MPR ${ }^{18}$, including in terms of the choice of a presidential system of government. Has this choice been carried out by scientific studies or scientific research, by exploring the traditions of the Indonesian nation state, as was done by the founding fathers, Soepomo, Soekarno, Moh Yamin and Hatta? In his writings, Hatta said that village democracy must be expanded in a state container that must be adapted to the times, so that village democracy can be developed in a modern nation state.${ }^{19}$ With the choice of a presidential government system, what is the role of the MPR and DPD in the relationship between the legislative and executive in the presidential system? And is it not clear in the presidential system the accountability of the government? The President's political accountability to the

\footnotetext{
${ }^{18}$ Mahfud MD, 2007, Perdebatan Hukum Tata Negara, LP3ES, Jakarta, p. 20

${ }^{19}$ Muhammad Hatta, 1977, Ke Arah Indonesia Merdeka. Dalam Miriam Budiardjo (ed.), Masalah Kenegaraan, Gramedia, Jakarta, p. 21
} 
people can only be assessed at the end of his term of office through general elections. So far, political accountability has no clear substance and meaning, whether the President has fulfilled his promises in accordance with the vision, mission and policy programs that have been campaigned for in the presidential election. The president's authority exists as long as he is in office. Consequently, the responsibility of the president is attached throughout the term of office of the President, but the accountability of the President directly to the people does not have a clear measure. Can the President's state speech, every time before independence day be seen as the President's public accountability to the people?

Aidul fitriciada in his research results said that the amendment to the 1945 Constitution also rejected the parliamentarism system because he believed that parliamentarism reflected the liberal system which historically created political instability in the 1950s. The amendments to the 1945 Constitution also rejected the original government system (quasi-presidential) in the 1945 Constitution and the parliamentary system. The MPR's agreement to amend the 1945 Constitution showed reasons that were based on historical reasons, not ideological ones. ${ }^{20}$ The historical reason for the rejection of the government system in the original 1945 Constitution means the rejection of the practice of authoritarianism that occurred in the Old Order and New Order governments. Ideologically, the rejection of the parliamentary system means rejecting the liberalism that was practiced in parliamentary democracy when it occurred in the $1950 \mathrm{s.}^{21}$

There is no coherence in the acceptance of the presidential system in the amendments to the 1945 Constitution, but it also rejects parliamentary liberalism. The founding fathers believed that the form of liberalism was also born by the American constitutionalism system. They have an ideological stance that rejects Western liberalism, both practiced in the European parliamentarism system and American presidentialism. ${ }^{22}$ Therefore, the founders of the state determined the choice of the government system in the 1945 Constitution before the amendment was a quasipresidential which was formulated among others in Article 4 paragraph (1) and Article 6 paragraph (2) of the 1945 Constitution.

What the founding fathers feared can be seen in the practice of presidentialism in the 1945 Constitution as a result of the amendments, how the practice of liberalism and capitalism can enter the realm of filling representative political positions and head positions, including the political office of the President which is contested in a general election held directly by the people. Direct presidential elections will greatly benefit the oligarchs who own capital, high social class groups because they have the resources to control the votes of the voters, this is especially the case in developing countries such as Indonesia. ${ }^{23}$

The choice of a government system by strengthening the presidential government system seems to continue to raise several problems in the 1945 amendments.

\footnotetext{
${ }^{20}$ Aidul Fitriciada Azhari, 2014, Rekonstuksi Tradisi Bernegara Dalam UUD 1945, Genta Publishing, Yogyakarta, p. 86

21 Ibid.

22 Ibid.

${ }^{23}$ See Aidul Fitriciada Azhari, 2016, Pemikir(an) Politik Hukum, dalam Sahabat Bicara Mahfud MD, penyunting Saldi Isra'-Edy Suandi Hamid PT RajaGrafindo Persada, Jakarta, p. 24
} 
Purification of the presidential system in Indonesia has been carried out, but there are still many problems that need to be reorganized, especially in the political infrastructure. The number of political parties in Indonesia that have legality in the constitution and in the law on political parties encourages the growth of democracy, but this will be a dilemma when juxtaposed with a presidential government system. In relation to the development of democracy according to Arbi Sanit ${ }^{24}$ "Representation in a multi-party system needs to be coherent with the Indonesian government system because otherwise, no matter how hard it is, democratization will not be built." ${ }^{25}$ Such a situation will strengthen the analysis that the presidential system implemented in a multi-party political system is doubtful to strengthen democratization and it is believed that there is a tendency to create conflict situations and imbalances between the presidential and DPR institutions which result in unstable democracy. ${ }^{26}$

No less important is what the general chairman of PP Muhamadiyah Haedar Nasir said that Indonesian politics demands the morals and values of "wisdoms" contained in the fourth precepts of Pancasila, not just politics of use-value and the principle of mere freedom. He further said that substantial democracy was increasingly defeated by pragmatic and liberal procedural democracy. Questioning who can stop money, transactional, dynastic and oligarchic politics as a result of procedural, liberal and overproductive democracy. Even in a number of ways and the process has experienced deviations and distortions from the spirit of Pancasila and the constitution that the founding fathers had built. ${ }^{27}$

The structure of Indonesian society has a high degree of pluralism, enabling the formation of a politically fragmented multi-party system. The vote of the President in the general election is not necessarily the same as the vote of the voter in the election of members of the DPR. This situation makes it difficult for the parties carrying the President and the elected President to form their own government because the votes acquired by political parties in the general election in the people's representative office environment, namely the DPR will be distributed almost evenly, cannot obtain a majority vote, so that the formation of a government requires a coalition with other parties who gets a seat in the DPR. ${ }^{28}$

The consequence of implementing a multi-party system and the implementation of a proportional electoral system with an open candidate list, opens up opportunities for the growth of many parties, this will have an impact on the level of party institutionalization is low and political power in parliament also tends to be fragmented. The fragmentation of political power is difficult to avoid because it has a fairly high level of party pluralism. Multi-party political power in the DPR tends to be evenly distributed,

\footnotetext{
${ }^{24}$ Arbi Sanit in seminar "Problems and Options of Indonesia Democracy" di UGM Yogyakarta, 9 December 2008, http://www.republika.co.id

${ }^{25}$ The adoption of a multi-party system in Indonesia is due to heterogeneous society, diversity of customs, beliefs and the spread of regions, of course, this has an impact on changes in the political constellation.

${ }^{26} J u a n$ Linz \& Arturo Velenzuela, The Failure of Presidential Democracy: The Case of Latin America, Johns Hopkins University, 1994 in Hanta Yuda AR, 2010, . Loc., Cit. p. 5

27 https:// Suaramuhammadiyah.id/2021/06/28/heidar-nasir-atasi-pandemi-hentikan-kontroversi/

${ }^{28}$ Siti Rodhiyah 2019, Pola Ideal Pertanggungjawaban Presiden Dalam Mewujudkan Demokrasi Ekonomi Menurut Undang Undang Dasar Negara Republik Indonesia Tahun 1945 Pada Era Reformasi, Summary of Doctoral Program (S3) Dissertation in Law at the Graduate School of UMS Surakarta, p. 116
} 
so it will be difficult to obtain a majority in parliament. This condition forces parties to form coalitions, both in the government (cabinet) and in parliament. ${ }^{29}$

Since the reform era, the term electoral threshold has been introduced which is interpreted as the minimum threshold for political parties to be able to participate in elections in the next period. With the existing political developments, almost every election period, a threshold rule is applied which is always revised with an ever-changing number of figures. Finally, an agreement was reached between the government and the DPR that the term electoral threshold was replaced with a parliamentary threshold ${ }^{30}$. There have been several judicial reviews of the threshold rules to the Constitutional Court, which are based on the reasons that the protection of human rights, especially civil and political rights that are injured, has no value and the number of votes cast is wasted with the implementation of the threshold, this will contrast with the implementation of the proportional elections system. However, this provision actually received a strengthening of the threshold setting in the Constitutional Court's decision No. 3/PUU-VII/2009, with a ruling stating that the application of the threshold is a natural thing in an effort to simplify political parties in a country. ${ }^{31}$

However, the parliamentary threshold in Act No. 7 of 2017 concerning General Elections is still applied as an effort to reduce the entry of political parties into parliament, as the limit for recruiting candidates for legislative or presidential members, which is $4 \%$ as regulated in Article 4014 paragraph (1). Retno Saraswati in her research even proposes: in real terms it is necessary to design to simplify the number of parties in parliamentary institutions, namely by consistently applying a parliamentary threshold of $5 \%$. It is calculated that the DPR will only have about 5 to 6 parties or it can be said in simple multiparty terms. The reduced number of parties in the DPR means that the number of factions in the parliament is also reduced. ${ }^{32}$ Are the provisions of the parliamentary threshold compatible with the fragmented political culture and what about the traditions of the Indonesian nation that have been explored by the founding fathers? Should we transplant a purely US presidential system of government, or a government system that is constructed in accordance with the political system and values of civility or the traditions of the Indonesian nation.

Several problems have been found, therefore the choice of strengthening the presidential government system needs to be reviewed in the Indonesian state administration. To understand this problem, as stated by Jurgen Habermas, "the unique spirit of the people-the first-truly modern form of collective identity-provides the cultural basis for the constitutional state" 33 . In the era of globalization, there is a tendency to strengthen ethno-nationalism again to reaffirm the national identity of a nation to build a state law system, especially for the Indonesian nation. However, it also does not rule out the entry of foreign influences because relations between nations are

\footnotetext{
${ }^{29}$ Retn Saraswati, Log Cit, p.138

28 Sholahudin Al-Fatih, 2019, Akibat Hukum Regulasi Tentang Threshhold Dalam Pemilihan Umum Legislatif \& Pemilihan Presiden, FH Universitas Muhammadiyah Malang, Jurnal Yudisial Vol. 12 No. 1April 2019, p. $17-38$

${ }^{31}$ Ibid.

${ }^{32}$ Retno Saraswati, 2012.....Op., Cit. p. 142.

${ }^{33}$ Jurgen Habermas, 1999, The Inclusion of the Other: Studies in Political Theory. Cambridge, Mass: The MIT Press., p. 113
} 
an option that cannot be ignored.

Related to the era of globalization, the study of legal transplantation to the legal system of a country must consider aspects of socio-cultural, economic structure, ideology or even the geographical background between the donor country and the transplant recipient country. These non-juridical factors are important to consider because the legal transplant process can lead to rejection of the 'immune system' for the recipient country which can cause serious problems in the donor recipient country. ${ }^{34}$ Thus, the system of government adopted by a nation does not have to be identical to the models prevailing in other countries.

Amendments to the 1945 Constitution apply an American-style presidentialism system which is a form of legal transplant chosen in the state administration system that does not consider juridical and non-juridical factors in determining the choice of the government system in the 1945 Constitution. The juridical problem for Indonesia, in this case the MPR institution which consists of members of the DPR and members of the DPD in the constitutional structure that is not functioned proportionally, it seems that it is only an ad hoc institution that functions when the state is in crisis. Whereas the MPR institution is a reflection of the social-collectivity described by the founding fathers in the life of the state in the constitution. The 1945 Constitution is a constitution which contains material on political democracy and socio-economic democracy,

What does it mean? When the president's annual state speech before independence day is always done in front of especially members of the DPR and members of the DPD, they are members of the MPR. The MPR cannot judge the state speech as a form of public accountability, or merely provide input or correction on the implementation of government (in a presidential system) in Indonesia, although it is also understood that the MPR no longer has the independent authority to impeach the President in political affairs, because the President is elected by the people. , although there is the possibility of dismissing the President when it is proven that he has violated the law through a process that is not simple.

\section{Closing}

The choice of a presidential government system becomes a problem when juxtaposed with a multi-party system (the phrase combined political parties) in the 1945 Constitution. The MPR did not choose a quasi-presidential system in the original 1945 Constitution or a parliamentary system and explicitly transplanted the American-style presidential government system, regardless of reasons. Ideology and identity as well as state traditions that have been explored by the founders of the nation such as Soepomo, Soekarno and Muhammad Hatta.

\section{References}

\section{Journals:}

\footnotetext{
${ }^{34}$ Aidul Fitriziada Azhari, 2014, Op., Cit., p. 17
} 
[1] A Chuasanga, Ong Argo Victoria. (2019). Legal Principles Under Criminal Law in Indonesia and Thailand, Jurnal Daulat Hukum, Vol 2, No 1 (2019) http://jurnal.unissula.ac.id/index.php/RH/article/view/4218

[2] Joko Susilo \& Siti Rodhiyah Dwi Istinah, "Peran Komisi Pemilihan Umum Daerah Kabupaten Semarang Dalam Meningkatkan Partisipasi Politik Masyarakat Pada Pemilu Serentak 2019" in the Proceedings of the Unissula Student Scientific Conference (KIMU) 2 Universitas Islam Sultan Agung Semarang, 18 October 2019, p. 532, http://jurnal.unissula.ac.id/index.php/kimuh/article/view/8861/4038

[3] José Antonio Cheibub, Zachary Elkins and Tom Ginsburg, "Beyond Presidentialism and Parliamentarism", British Journal of Political Science, Available on CJO 2013 doi:10.1017/S000712341300032X.

[4] Mei Susanto, Rahayu Prasetya ningsih, \& Lailani Sungkar, Jurnal Penelitian Hukum De Jure Akreditasi LIPI: No: 740/AU/P2MI-LIPI/04/2016, Volume18 No.1, Maret 2018, hlm. 24. Diakses pada tgl 16 Pebruari 2021

[5] Muhammad Asrun, The Practice of Presidential System in Indonesia, Scientific Research Journal (SCIRJ), Volume III, Issue IV, April 201515 ISSN 2201-2796, www.scirj.org.

[6] Retno Saraswati, Desain Sistem Pemerintahan Presidensial yang Efektif, Faculty of Law, Universitas Diponegoro Semarang, in Jurnal Masalah-masalah Hukum, Jilid 41 No. 1 January 2012

[7] Ribkha Annisa Octovina, Sistem Presidensial di Indonesia, CosmoGov: Jurnal IImu Pemerintahan, ISSN 2442-5958 E-ISSN 2540-8674, Vol.4, No.2, October 2018

[8] Richard Albert; Presidential values in parliamentary democracies, International Journal of Constitutional Law, Volume 8, Issue 2, 1 April 2010, Pages 207, https://doi.org/10.1093/icon/moq008

[9] Richard Benwell and Oonagh Gay, The Separation of Powers,Standard Note: SN/PC/06053, House of Commons Library, p. 3. http://researchbriefings.files.parliament.uk/documents/SN06053/SN06053.pdf.

[10] Sholahudin Al-Fatih, 2019, Akibat Hukum Regulasi Tentang Threshhold Dalam Pemilihan Umum Legislatif \& Pemilihan Presiden, FH Universitas Muhammadiyah Malang, Jurnal Yudisial Vol. 12 No. 1 April 2019

[11] Uchem Raphael Onyebuchi, "Executive, Legislative Relations In Parliamentary And Presidential Government", dalam Global Journal of Arts Humanities and Social Sciences Vol. 1 No. 3, p. 14-19, September 2013 [Published by European Centre for Research Training and Development UK (www.ea-journals.org).

\section{Books:}

[1] Aidul Fitriciada Azhari, 2014, Rekonstuksi Tradisi Bernegara Dalam UUD 1945, Genta Publishing, Yogyakarta

[2] Aidul Fitriciada Azhari, 2016, Pemikir(an) Politik Hukum, dalam Sahabat Bicara Mahfud MD, penyunting Saldi Isra'-Edy Suandi Hamid PT RajaGrafindo Persada, Jakarta

[3] Allan R. Ball \& B. Guy Peters, 2000, Modernn Politics and Government, edisi ke-6, Macmillan Press Ltd, dalam Saldi Isra, 2010, Pergeseran Fungsi Legislasi, Rajawali Pers, Jakarta. 
[4] Hamid S. Attamimi, 1990, Peranan Keputusan Presiden Republik Indonesia Dalam Penyelenggaraan Pemerintahan Negara, Suatu Analisis Mengenai Keputusan Presiden Yang Berfungsi Pengaturan Dalam Kurun Waktu pelita I-Pelita IV, Disertasi, Fak. Pascasarjana UI, Jakarta.

[5] Juan Linz \& Arturo Velenzuela, The Failure of Presidential Democracy: The Case of Latin America, Johns Hopkins University, 1994 dalam Hanta Yuda AR, 2010

[6] Mhfud MD, 2007, Perdebatan Hukum Tata Negara, LP3ES, Jakarta

[7] Muhammad Hatta, 1977, Ke Arah Indonesia Merdeka. Dalam Miriam Budiardjo (ed.), Masalah Kenegaraan, Gramedia, Jakarta

[8] Philipus M Hadjon, 1991, Pelimpahan Tugas \& Wewenang Kepada Presiden, Dalam Rangka Mensukseskan \& Mengamankan Pembangunan Nasional, Makalah, Universitas Airlangga, Surabaya

[9] Siti Rodhiyah 2019, Pola Ideal Pertanggungjawaban Presiden Dalam Mewujudkan Demokrasi Ekonomi Menurut Undang Undang Dasar Negara Republik Indonesia Tahun 1945 Pada Era Reformasi, Ringkasan Disertasi Program Doktor (S3) Ilmu Hukum Sekolah PascaSarjana UMS Surakarta.

[10] Sofian Effendi, 2018, Sistem Pemerintahan Adalah Jati Diri Bangsa, Makalah, UGM, Yogyakarta.

[11] Sri Soemantri, 1976, Sistem-Sistem Pemerintahan Negara-Negara Asean, Tarsito, Bandung

\section{Internet:}

[1] Arbi Sanit in seminar "Problems and Options of Indonesia Democracy" di UGM Yogyakarta, 9 December 2008, http://www.republika.co.id

[2] https://Suaramuhammadiyah.id/2021/06/28/heidar-nasir-atasi-pandemihentikan-kontroversi 